\title{
Increasing Lignification in Translucent Disorder Aril of Mangosteen Related to the ROS Defensive Function
}

\author{
Chalermchai Wongs-Aree $\mathbb{D}^{1},{ }^{1}$ Patchayapon Siripirom, ${ }^{2}$ Apinya Satitpongchai, ${ }^{2}$ \\ Kitti Bodhipadma $\mathbb{D}^{2}{ }^{2}$ and Sompoch Noichinda $\mathbb{D}^{2}$ \\ ${ }^{1}$ Division of Postharvest Technology, School of Bioresources and Technology, King Mongkut's University of Technology Thonburi, \\ Bangkhuntien, Bangkok 10150, Thailand \\ ${ }^{2}$ Division of Agro-Industrial Technology, Faculty of Applied Science, King Mongkut's University of Technology North Bangkok, \\ Bang-sue, Bangkok 10800, Thailand
}

Correspondence should be addressed to Sompoch Noichinda; sompoch.n@sci.kmutnb.ac.th

Received 27 November 2020; Revised 22 January 2021; Accepted 27 January 2021; Published 15 February 2021

Academic Editor: Giorgia Liguori

Copyright (c) 2021 Chalermchai Wongs-Aree et al. This is an open access article distributed under the Creative Commons Attribution License, which permits unrestricted use, distribution, and reproduction in any medium, provided the original work is properly cited.

\begin{abstract}
Mangosteen fruit has a high potential on the global fruit market, but some disorders, including translucent flesh, are major problems of fruit quality, limiting the marketability. The present study was conducted to compare physiological changes of reactive oxygen species (ROS), cellular lignification between translucent and normal aril, and elucidate the relation. Mangosteen fruits at purple peel color were collected from eastern Thailand during the middle of the rainy season of 2019. Translucent aril accumulated higher lignin content in the tissues, expressing firmer texture ten times higher than normal aril. Lignification was increased in translucent aril by $740 \%$ and $25 \%$ higher coniferyl alcohol dehydrogenase (CAD) and peroxidase (POD) activity, respectively, induced by high $\mathrm{H}_{2} \mathrm{O}_{2}$. Healthy aril performed higher activities of superoxide dismutase (SOD) (8.5 times) and ascorbate peroxidase (APX) (1.3 times) to those in translucent aril. Furthermore, the higher flavonoid content, ascorbic acid content, and antioxidant capacities detected in normal aril could significantly reduce oxidative stress. Although containing high antioxidant systems, healthy aril was found to accumulate higher malonaldehyde content (MDA). This study provides intensive evidence of oxidative stress and the defensive systems between normal and translucent tissues.
\end{abstract}

\section{Introduction}

Mangosteen (Garcinia mangostana) belongs to the Guttiferae family. It is a unique tropical fruit, expressing prominent calyx on top of the fruit looking like a crown and so-called the 'Queen of fruit.' Mangosteen fruit consists of a thick pericarp derived from the floral ovary wall and 5-7 aril segments. The edible part (aril) is developed from the seed integument. The periodical cycle of fruit growth from flower opening until maturity takes about 11-12 weeks [1]. The fruit ripening starts by the pericarp color turning from pale green to purple followed by aril softening [2]. When mature green fruit starts ripening with the peel showing a red pad sign, mangosteen is classified as a climacteric fruit according to its respiratory pattern [3]. However, mangosteen fruit shows uneven ripening among aril segments in the fruit [4]. Furthermore, abnormal symptoms, including aril translucency and stiff texture of the aril, could be operated during ripening maturation. These disorders are severe obstacles in mangosteen marketability.

Translucent flesh disorder usually occurs during on-tree fruit ripening during the rainy season. The previous study showed that the number of fruits generating flesh translucency increased when the tree was applied by water sprinkling over the canopy for 2-3 h [5]. On the other hand, a high level of underground water did not stimulate the induction of translucent flesh disorder [6]. Moreover, an application of water supplied at the harvested fruit peduncle did not induce translucent flesh disorder in ripe fruit [3]. Since capillary water (lenticel-occupied water) in the 
pericarp of on-tree mature green fruit induced a hypoxic condition, this incident enhanced translucent flesh disorder which found a remarkable accumulation of lignin in the ripe aril [7]. Furthermore, our previous study found a significantly high proportion of $\mathrm{Na}_{2} \mathrm{CO}_{3}$-SP between differential pectin fractions of translucent disorder aril [7]. A comparison of respiratory patterns indicates that translucent disorder aril conducted a higher respiration rate than healthy aril [8]. Typically, translucent disorder initially occurs in the largest aril segment, which showed high vigorous energies in both aril and seed than healthy arils [9]. As hypoxic cellular conditions are stimulated by alternative catabolic pathways to produce more energy for maintaining systematic survival, these stress phenomena could be encouraged by the overemission of reactive oxygen species (ROS) in several plant parts $[10,11]$. The ROS directly attacks the cell membrane or is transformed into a harmful hydroxyl radical $(\mathrm{OH})$, enhancing the lipid membrane's peroxidation. However, ROS can be subsequently reduced by some biological pathways, including cellular defensive mechanisms. Plants under stress drive their defensive resilience through the alternative antioxidant systems, both enzymatic and nonenzymatic shuttles. The enzymatic system includes superoxide dismutase (SOD), catalase (CAT), and ascorbate peroxidase (APX). On the other hand, phenolics, flavonoids, and ascorbates are involved in preventing stress. Some abiotic stresses inducing the defensive mechanisms in plants through ROS metabolisms have been recently reported [12-15]. Thus, the purposes of this research were to investigate ROS generations, phenolic accumulation, and lignification and to explore the relation of enzymes associated with ROS removal in ripe mangosteen aril between the healthy and translucent tissues.

\section{Materials and Methods}

2.1. Plant Materials. Fresh ripe mangosteen fruits at the peel purple stage were obtained from a commercial orchard in Chanthaburi Province, eastern Thailand, in July 2019, and were transported to the Applied Science Laboratory at King Mongkut's University of North Bangkok (KMUTNB) within a day. Fruits were then sorted by the uniformity of size (ca. $70-90 \mathrm{~g} /$ fruit), peel color, and absence of defects. For a preliminary classification of translucent flesh disorder, fruits were floated onto water containing $1.0 \%$ sodium chloride. The fruit that sank in the solution was presumed as having translucent flesh disorder, comprising higher gravity. After air-drying at the ambient room temperature $\left(23-28^{\circ} \mathrm{C}\right)$, the fruit pericarp was carefully removed by a sharp knife without aril damage. In the present study, the fruit largest aril segment of normal white (Supplementary Figure 1(a)) and translucent disorder flesh (Supplementary Figure 1(b); pointing arrow) was collected from one hundred mangosteen fruits for investigating the ROS stress and lignification.

2.2. Firmness Measurement. Aril firmness was measured in the middle of the segment by using a TA-XT 21 texture analyzer (Stable Microsystems, UK) using a $2 \mathrm{~mm}$ spherical plunger with $5 \mathrm{~mm}$ distance depth and $1.0 \mathrm{~mm} \cdot \mathrm{s}^{-1}$ test speed. The maximum force was recorded in Newton unit.

2.3. Cross Section and Staining. A thin piece of free-hand cross section (40 microns) from normal and translucent disorder arils was stained with $0.1 \mathrm{M}$ potassium phosphate buffer ( $\mathrm{pH}$ 6.8) containing $0.05 \%(\mathrm{w} / \mathrm{v})$ Toluidine Blue O-dye for $2 \mathrm{~min}$ and then washed with distilled water [16]. The stained tissues were observed under a light microscope (EMZ, Meiji Techno, Japan).

2.4. Lignin Determination. Lignin content in the flesh was investigated according to the method of Bruce and West [17]. Four $g$ of aril flesh was homogenized in $16 \mathrm{~mL}$ of methanol by using a homogenizer (IKA Ultrarax $T$ 25, Germany). Homogenate was filtered through Whatman GF/Ag filter No. 1. The remaining residual was washed twice by methanol and dried in an oven at $60^{\circ} \mathrm{C}$ for $24 \mathrm{~h}$. Fifty mg of dried residual was mixed in $5 \mathrm{~mL}$ of $2 \mathrm{M}$ hydrochloric acid and $0.5 \mathrm{~mL}$ of thioglycolic acid. The mixture was boiled at $100^{\circ} \mathrm{C}$ for $4 \mathrm{~h}$. After cooling, the suspension was centrifuged at $12,000 \times g$ for $30 \mathrm{~min}$. The pallet was rinsed with $5 \mathrm{~mL}$ of distilled water. The pallet was mixed in $5 \mathrm{~mL}$ of $0.5 \mathrm{M}$ sodium hydroxide for lignin thioglycolate extraction and left for $18 \mathrm{~h}$. The mixture was centrifuged at $12,000 \times g$ for $30 \mathrm{~min}$. The supernatant $(1 \mathrm{~mL})$ was added with $1 \mathrm{~mL}$ of concentrated hydrochloric acid and incubated for $4 \mathrm{~min}$. The reaction was centrifuged at $10,000 \times \mathrm{g}$ for $10 \mathrm{~min}$. The radish-brown residual was collected and dissolved in $25 \mathrm{~mL}$ of $0.5 \mathrm{M}$ sodium hydroxide. The dissolved lignin solution's absorbance was measured by using a spectrophotometer (Shimadzu UV-1800, Japan) at $280 \mathrm{~nm}$. The content was reported in $\mathrm{Abs}_{280} \mathrm{~nm} / 50 \mathrm{mg}$ DW.

\subsection{ROS Generation and Its Transformation Determination.} Superoxide anion $\left(\mathrm{O}_{2}^{-}\right)$was extracted and measured according to Chaitanya and Naithani [18]. Two $g$ of aril flesh was homogenized in $5 \mathrm{~mL}$ of $0.05 \mathrm{M}$ potassium phosphate buffer ( $\mathrm{pH} 7.8$ ) including $1 \mathrm{mM}$ diethyl-dithiocarbamate (a SOD inhibitor). The homogenate was centrifuged at $12,000 \times \mathrm{g}$ at $4^{\circ} \mathrm{C}$ for $15 \mathrm{~min}$. The supernatant $(1 \mathrm{~mL})$ was added with $3 \mathrm{~mL}$ of a reaction mixture containing $0.1 \mathrm{M}$ phosphate ( $\mathrm{pH}$ 7.8), $1 \mathrm{mM}$ diethyl-dithiocarbamate, and $0.25 \mathrm{mM}$ nitro blue tetrazolium (NBT). The absorbance of the reaction solution was spectrophotometrically measured at $540 \mathrm{~nm}$ within a min.

Hydrogen peroxide $\left(\mathrm{H}_{2} \mathrm{O}_{2}\right)$, an $\mathrm{O}_{2}^{--}$transformation, was measured according to the work of Zouari et al. [19]. One $g$ of aril was homogenized in $5 \mathrm{~mL}$ of $0.1 \%$ trichloroacetic acid (TCA) and centrifuged at $12,000 \times g$ at $4^{\circ} \mathrm{C}$ for $15 \mathrm{~min}$. The supernatant $(1 \mathrm{~mL})$ was then added to $2 \mathrm{~mL}$ of a reaction mixture containing $0.01 \mathrm{M}$ potassium phosphate buffer $(\mathrm{pH}$ 7.0 ) and $1 \mathrm{M}$ potassium iodide. The reaction absorbance was spectrophotometrically measured at $390 \mathrm{~nm}$.

2.6. ROS Defensive Enzyme Assays. Extracts of superoxide dismutase (SOD), catalase (CAT), peroxidase (POD), and ascorbate peroxidase (APX) were performed according to 
the methods of Dhindsa et al. [20] and Jiménez et al. [21]. For SOD, POD, and CAT, $1 \mathrm{~g}$ of aril flesh was homogenized in $10 \mathrm{~mL}$ of $0.05 \mathrm{M}$ potassium phosphate buffer $(\mathrm{pH} 7)$ containing $1 \%(\mathrm{w} / \mathrm{v})$ polyvinylpolypyrrolidone (PVPP). For APX extraction, $1 \mathrm{~g}$ of aril flesh was homogenized in $10 \mathrm{~mL}$ of $0.05 \mathrm{M}$ potassium phosphate buffer ( $\mathrm{pH}$ 7.8) containing $0.1 \%(\mathrm{v} / \mathrm{v})$ Triton X-100. The homogenate was centrifuged at $12,000 \times \mathrm{g}$ at $4^{\circ} \mathrm{C}$ for $15 \mathrm{~min}$, and the supernatant was used for activity assay.

The extraction and assay of CAD were performed with the slightly modified Goffner et al. [22]. Briefly, $2 \mathrm{~g}$ of aril was homogenized in $10 \mathrm{~mL}$ of $100 \mathrm{mM}$ phosphate buffer ( $\mathrm{pH} 7.5$ ) containing $1 \mathrm{mM}$ EDTA, $5 \mathrm{mM}$ magnesium chloride, $0.05 \%$ (v/v) Tween 20, and $2.5 \mathrm{mM} 2$-mercaptoethanol. The homogenate was high-speed centrifuged at $18,000 \times g$ at $4^{\circ} \mathrm{C}$ for $30 \mathrm{~min}$. The supernatant was used for enzyme activity assay. One $\mathrm{mL}$ of the crude enzyme was incubated in $3 \mathrm{~mL}$ of $100 \mathrm{mM}$ phosphate buffer $(\mathrm{pH}$ 7.5) containing $0.2 \mathrm{mM}$ NADP and $0.1 \mathrm{mM}$ coniferyl alcohol for $1 \mathrm{~min}$. The activity of the enzyme was measured by using a spectrophotometer at $400 \mathrm{~nm}$.

SOD activity assay was perfprmed according to the work of Dhindsa et al. [20]. The crude $(100 \mu \mathrm{L})$ was mixed in $3 \mathrm{~mL}$ of $0.05 \mathrm{M}$ potassium phosphate buffer $(\mathrm{pH}$ 7.8) containing $13 \mathrm{mM}$ methionine, $75 \mathrm{mM} \mathrm{NBT}, 4 \mathrm{mM}$ riboflavin, and $100 \mu \mathrm{M}$ ethylene diamine tetra-acetic acid. The solution mixture was vortexed for $1 \mathrm{~min}$ and then left under fluorescent light (15 watts) for $30 \mathrm{~min}$. The absorbance was spectrophotometrically measured at $560 \mathrm{~nm}$. SOD activity was calculated from the reaction mixture's absorbency with the enzyme (sample) and without enzyme (control). One unit of SOD activity was represented by $50 \%$ NBT inhibition calculated from the following formula:

$$
\operatorname{SOD}\left(\frac{\text { unit }}{g \mathrm{FW}}\right)=\frac{\left(\mathrm{Abs}_{\text {Control }}-\mathrm{Abs}_{\text {Sample }} / \mathrm{Asb}_{\text {Control }} \times 100\right)}{2} .
$$

POD and CAT activity assays were performed according to Song et al.'s method [23]. One hundred $\mu \mathrm{L}$ of the crude extract was mixed in $3 \mathrm{~mL}$ of $0.05 \mathrm{M}$ potassium phosphate buffer ( $\mathrm{pH}$ 7.0) containing $200 \mathrm{mM}$ hydrogen peroxide and $20 \mathrm{mM}$ guaiacol. The absorbance of POD was measured at $470 \mathrm{~nm}$. One POD activity unit was represented by an increase in the absorbance (0.01) in $1 \mathrm{~min}$. For CAT activity, $100 \mu \mathrm{L}$ of the crude was mixed in $3 \mathrm{~mL}$ of $0.05 \mathrm{M}$ potassium phosphate buffer ( $\mathrm{pH}$ 7.0) containing $200 \mathrm{mM}$ hydrogen peroxide. The absorbency was measured at $240 \mathrm{~nm}$. One unit of CAT activity was represented by a decrease in the absorbance $(0.01)$ for $1 \mathrm{~min}$.

2.7. Malondialdehyde (MDA) Determination. Determination of MDA was performed according to Dipierro and Leonardis [24]. Two $g$ of aril flesh was homogenized in $10 \mathrm{~mL}$ of $0.1 \%$ $(\mathrm{w} / \mathrm{v})$ trichloroacetic acid (TCA) and centrifuged at $12,000^{\circ} \times{ }^{\circ} \mathrm{g}$ for $10 \mathrm{~min}$. The supernatant $(1 \mathrm{~mL})$ was reacted with $2 \mathrm{~mL}$ of $20 \%(\mathrm{v} / \mathrm{v})$ TCA containing $0.5 \%(\mathrm{v} / \mathrm{v})$ of thiobarbituric acid (TBA) and incubated in a hot bath at $100^{\circ} \mathrm{C}$ for $10 \mathrm{~min}$ and then cooled down on ice. The absorbances were spectrophotometrically measured at 532 and $600 \mathrm{~nm}$, respectively. MDA content was calculated from the following formula with $155 \mathrm{mM}^{-1} \mathrm{~cm}^{-1}$ extinction coefficient value:

$$
\operatorname{MDA}\left(\frac{\mu \mathrm{mol}}{g \mathrm{FW}}\right)=\left(\frac{\mathrm{Abs}_{532 \mathrm{~nm}}-\mathrm{Abs}_{600 \mathrm{~nm}}}{155 \mathrm{mM}^{-1} 1 \mathrm{~cm}^{-1} \times 1000}\right) .
$$

\subsection{Phenolics Accumulation and Phenylalanine Ammonia} Lyase (PAL) Activity Assay. Determination of aril phenolics was performed according to Recuenco et al.'s method [25]. One $g$ of flesh was homogenized in $10 \mathrm{~mL}$ of methanol. After centrifugation at $10,000 \times g$ for $15 \mathrm{~min}$, the supernatant $(100 \mu \mathrm{L})$ was mixed in $3 \mathrm{~mL}$ of distilled water and $0.5 \mathrm{~mL}$ of Folin-Ciocalteu phenol reagent for $3 \mathrm{~min}$. The mixture was added with $2 \mathrm{~mL}$ of $20 \%(\mathrm{w} / \mathrm{v})$ of sodium carbonate. The absorbance of the reaction was recorded at $750 \mathrm{~nm}$. Phenolic acid content was compared to the absorbance of gallic acid standard. For flavonoid determination, $2 \mathrm{~mL}$ of supernatant was mixed in $5 \mathrm{~mL}$ of distilled water and $0.15 \mathrm{~mL}$ of $5 \%(\mathrm{w} / \mathrm{v})$ sodium nitrate for $5 \mathrm{~min}$, and then, $0.15 \mathrm{~mL}$ of $10 \%(\mathrm{w} / \mathrm{v})$ aluminium chloride was added. The reaction absorbance was measured at $510 \mathrm{~nm}$. Flavonoid content was compared with catechin standard.

PAL assay was performed according to the work of Camm and Towers [26]. Five $g$ of flesh was homogenized in $60 \mathrm{~mL}$ of cold acetone and filtered through Whatman filter paper No. 2. The remaining brown residual was rewashed with cold acetone until the residual color turned white. The residual was blended in $50 \mathrm{~mL}$ of cold $95 \%$ ethanol and filtered through Whatman filter paper No. 2. The residual was dried at room temperature $\left(25^{\circ} \mathrm{C}\right)$ and then kept in a desiccant chamber. For PAL, $0.5 \mathrm{mg}$ of the acetone powder was mildly stirred in $50 \mathrm{~mL}$ of $0.1 \mathrm{M}$ sodium borate buffer ( $\mathrm{pH} 8.8)$ at $4^{\circ} \mathrm{C}$ for $30 \mathrm{~min}$. After centrifugation at $12,000 \times \mathrm{g}$ at $4^{\circ} \mathrm{C}$ for $20 \mathrm{~min}$, the supernatant $(1 \mathrm{~mL})$ was mixed in $1.5 \mathrm{~mL}$ of $0.1 \mathrm{M}$ sodium borate buffer $(\mathrm{pH}$ 8.8 ) and $1 \mathrm{~mL}$ of $10 \mathrm{mg} / \mathrm{mL}$ phenylalanine and incubated in a hot bath at $30^{\circ} \mathrm{C}$ for $1 \mathrm{~h}$. Five $\mathrm{N} \mathrm{HCl}(0.5 \mathrm{~mL})$ was added into the reaction to stop the enzyme activity. The reaction absorbance with and without phenylalanine was measured at $290 \mathrm{~nm}$. One unit of PAL activity was represented by an increase in $1 \mu \mathrm{mol}$ cinnamic acid per $1 \mathrm{~h}$.

2.9. Ascorbic Acid Determination. An ascorbic acid determination was performed, according to Klein and Perry's method [27]. One $g$ of aril flesh was homogenized in $10 \mathrm{~mL}$ of $5 \%(\mathrm{w} / \mathrm{v})$ metaphosphoric acid and centrifuged at $12,000 \times \mathrm{g}$ for $10 \mathrm{~min}$. The supernatant $(0.5 \mathrm{~mL})$ was mixed in $4.5 \mathrm{~mL}$ of $0.1 \mathrm{mM} \mathrm{2,6-DCIP.} \mathrm{The} \mathrm{absorbance} \mathrm{of} \mathrm{ascorbic} \mathrm{acid} \mathrm{in} \mathrm{the}$ mixture was then spectrophotometrically measured at $515 \mathrm{~nm}$ and compared to the ascorbic acid standard curve.

\subsection{Antioxidant Ability Assays}

2.10.1. Reducing power Assay. One $g$ of aril flesh was homogenized in $9 \mathrm{~mL}$ of methanol with a homogenizer. The homogenate was made to stand at ambient temperature 


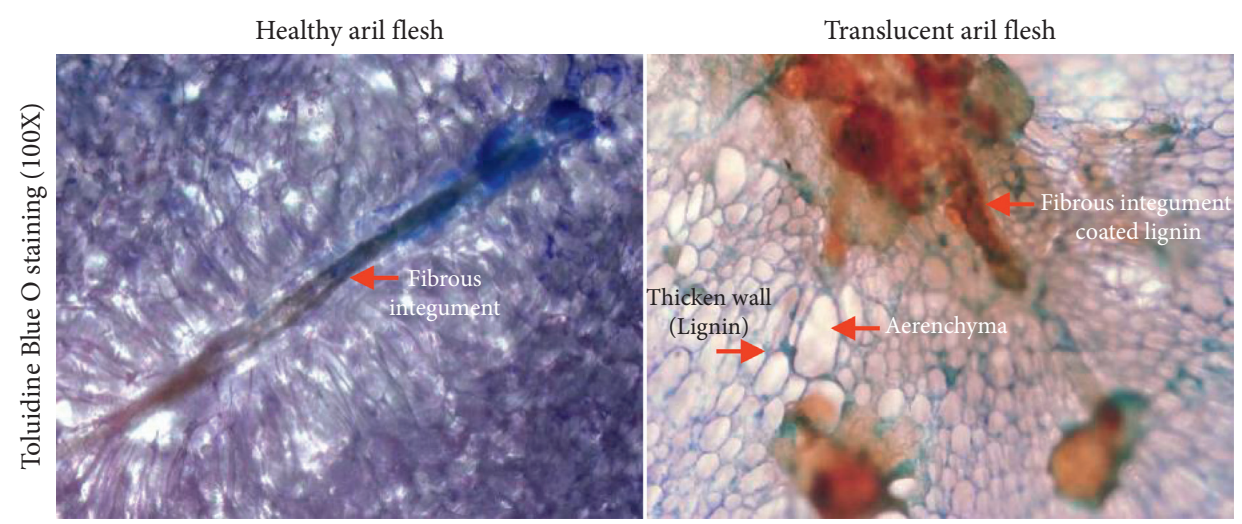

(a)

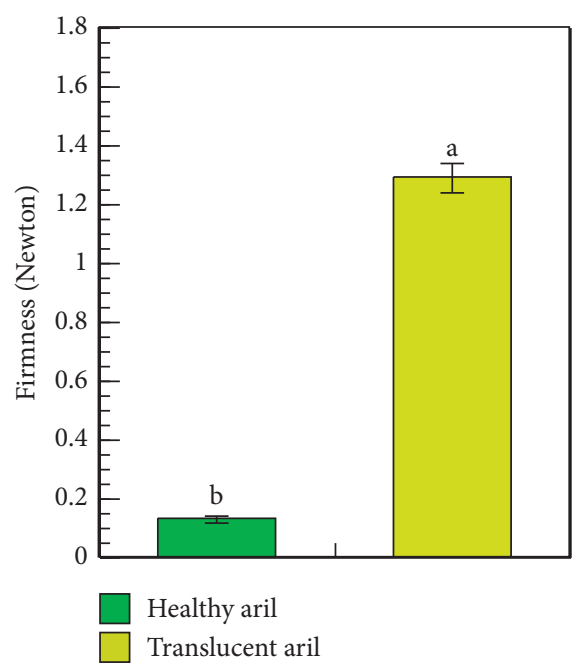

(b)

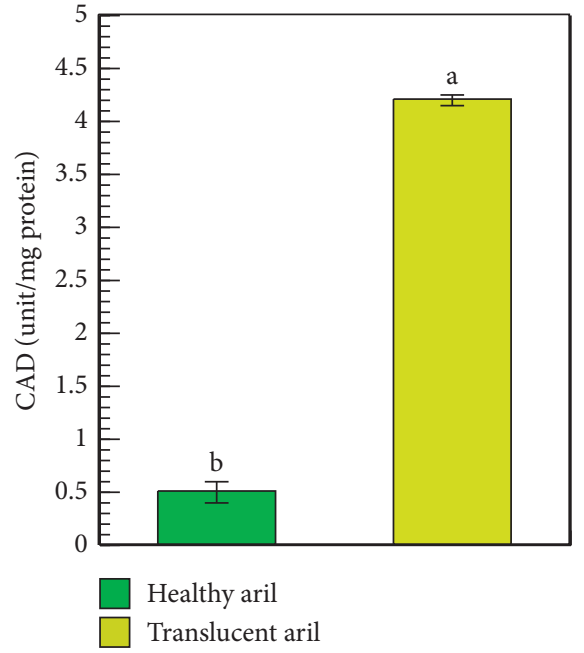

(d)

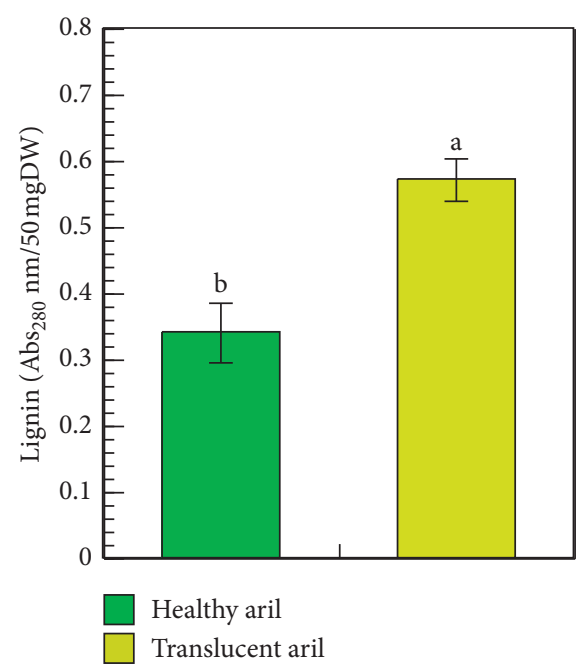

(c)

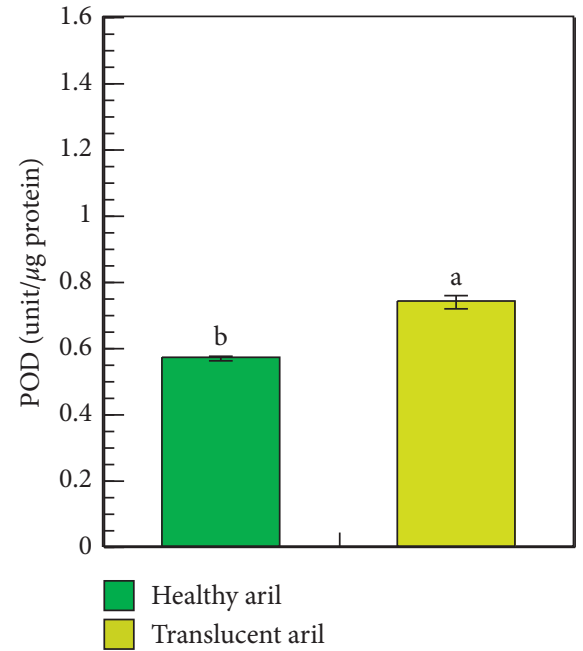

(e)

FIgUre 1: Toluidine Blue O-stained tissues (a), firmness (b), lignin content (c), coniferyl alcohol dehydrogenase activity (d), and peroxidase activity (e) in healthy and translucent arils. Means $(n=4)$ with different lower-case letters on the bars are significantly different. 
$\left(24-28^{\circ} \mathrm{C}\right)$ for $3 \mathrm{~h}$ and then suctioned through Whatman filter paper No. 1. The methanolic supernatant $(5 \mathrm{~mL})$ was mixed with $1.25 \mathrm{~mL}$ of $0.2 \mathrm{M}$ potassium phosphate buffer (pH 6.6) and $1.25 \mathrm{~mL}$ of $1.0 \%$ potassium ferricyanide (w/v). The mixture was then incubated in a hot water bath at $50^{\circ} \mathrm{C}$ for $20 \mathrm{~min}$. The mixture was cooled down on ice before adding $1.25 \mathrm{~mL}$ of $10 \%(\mathrm{w} / \mathrm{v})$ trichloroacetic acid. The cleared zone fraction $(2.5 \mathrm{~mL})$ was mixed with $2.5 \mathrm{~mL}$ of distilled water and $0.5 \mathrm{~mL}$ of $0.1 \%(\mathrm{w} / \mathrm{v})$ ferric chloride and incubated at ambient temperature for $10 \mathrm{~min}$. The absorbance of the solution mixture was spectrophotometrically measured at $700 \mathrm{~nm}$ [24].

2.10.2. DPPH Scavenging Inhibition Assay. DPPH scavenging ability was measured, according to Chang et al. [28]. One $g$ of aril flesh was homogenized in $10 \mathrm{~mL}$ of methanol and centrifuged at $10,000 \times g$ for $15 \mathrm{~min}$. The supernatant $(0.1 \mathrm{~mL})$ was added into $2.9 \mathrm{~mL}$ of $1 \mathrm{mM} 1,1$ diphenyl-2-picrylhydrazyl (DPPH) and kept in the dark condition for $30 \mathrm{~min}$. Then, mixture absorbance was monitored at $517 \mathrm{~nm}$. The reaction without the methanolextraction solution was demonstrated as a control. The percentage of scavenging inhibition was calculated from the following formula:

$$
\text { DPPH inhibition }(\%)=\frac{\left(\mathrm{Abs}_{\text {Control }}-\mathrm{Abs}_{\text {Sample }}\right)}{\mathrm{Abs}_{\text {Control }}} \times 100 .
$$

2.11. Protein Determination. Protein content in the enzyme reaction was measured according to Bradford's method [29]. The crude at $0.5 \mathrm{~mL}$ was mixed in a protein reagent composed of $100 \mathrm{mg}$ of Coomassie Brilliant Blue G-250 (CBB) in $50 \mathrm{~mL}$ of ethanol and $100 \mathrm{~mL}$ of $85 \%$ (w/v) phosphoric acid. The absorbance was recorded at $595 \mathrm{~nm}$ and then compared to Bovine Serum Albumin (BSA) standard.

2.12. Statistical Analysis. Independent Sample $t$-test analysis was performed to compare the variation of the parameter mean values between both treatments ( 4 replicates each; 4 fruit/replicates) at $p<0.05$ using an SPSS software version 26 (IBM, Chicago, IL, USA).

\section{Results and Discussion}

3.1. Lignification and Firmness. Translucent aril, behaving as a stiffening structure, exhibits firm-crispy texture and a translucent tissue character. The microscopic images of Toluidine Blue O-stained aril structure show that lignin was localized in the parenchyma cell wall and high in the protruding fibrous-chain of the seed coat of translucent flesh disorder (Figure 1(a)). Moreover, we found that some parenchyma cells in translucent tissues were either transformed into collenchyma cells or collapsed to form aerenchyma. The firmness of healthy aril was only 0.21 Newtons, which was 10 times lower than that of translucent aril (Figure 1(b)). This evidence was related to the higher lignin content detected in the translucent tissues, double the amount compared to healthy arils (Figure 1(c)). The translucent aril conducted high lignification, which was increased by the activity of two key enzymes in lignin biosynthesis, namely, CAD and POD. When the former increased by $740 \%$ (Figure 1(d)), the latter was $25 \%$ up (Figure 1(e)) in the translucent aril. From these two enzymes directly involved in the accumulation of lignins, CAD could be the rate-limiting step of lignification in mangosteen aril under the stress conditions. Translucent flesh disorder is usually generated in mangosteen fruit during fruit ripening developed on tree in the rainy season. Water covering the fruit could induce hypoxic and oxidative stress in the fruit [5]. Lignification induction was found in wheat under waterlogging conditions related to increasing CAD and POD activities [10]. The modification of lignins in the cell wall, simultaneously induced by abiotic stress, could modify the cell-wall matrix and the properties. Schopfer [30] reported that cell-wall stiffening of maize coleoptile was related to an intercellular coupling of monolignol residues by POD, a lignin bound-membrane enzyme, using $\mathrm{H}_{2} \mathrm{O}_{2}$ as an electron acceptor. As a result, changes in a high proportion of $\mathrm{Na}_{2} \mathrm{CO}_{3}$-SP in the pectin [7] and the high lignification could transform the white soft aril tissues into translucent crispy tissues under stress conditions.

3.2. ROS Generation and Its Transformation. Oxidative intermediates were investigated in both healthy and translucent arils of mangosteen fruit. Superoxide anion $\left(\mathrm{O}_{2}^{--}\right)$was dramatically higher in translucent aril, which was 8.5 -fold compared to a healthy one (Figure 2(a)). This harmful ROS was suddenly dismutated to hydrogen peroxide $\left(\mathrm{H}_{2} \mathrm{O}_{2}\right)$ by superoxide dismutase (SOD). When $\mathrm{H}_{2} \mathrm{O}_{2}$ content was $125 \%$ higher accumulated in translucent aril (Figure 2(b)), SOD activities were, however, equal in both healthy and translucent arils (Figure 2(c)). Levels of lipid peroxidation could imply oxidative stress and damage. Interestingly, malonaldehyde (MDA), a membrane-damaged end-product by lipid peroxidation, was slightly higher in healthy aril (Figure 2(d)). MDA is widely used as a marker of oxidative lipid injury in plant tissues under biotic and abiotic stress. However, this reaction in plant tissues could be potentially interfered by many biological compounds which vary according to the tissue types and stress conditions [31]. For oxidative stress in mangosteen fruit, $\mathrm{H}_{2} \mathrm{O}_{2}$ in healthy aril could be transformed into hydroxyl radical $\left(\mathrm{OH}^{\prime}\right)$ via Fenton reaction in the presence of $\mathrm{Fe}^{2+}$ than translucent aril. Alternatively, $\mathrm{H}_{2} \mathrm{O}_{2}$ was contributed to be a cosubstrate of POD to produce lignins in translucent aril, which is higher than that in healthy aril. Oxidative intermediates such as $\mathrm{O}_{2}^{-}$ and $\mathrm{H}_{2} \mathrm{O}_{2}$ were highly induced in okra pods [12] and asparagus shoots [32] during storage under abiotic stress. Furthermore, Jia et al. [11] found that cherry rootstock released a high ROS amount under waterlogging conditions. For survival, the harmful radical was discriminated by a scavenging mechanism using several enzymes and cosubstrates. 


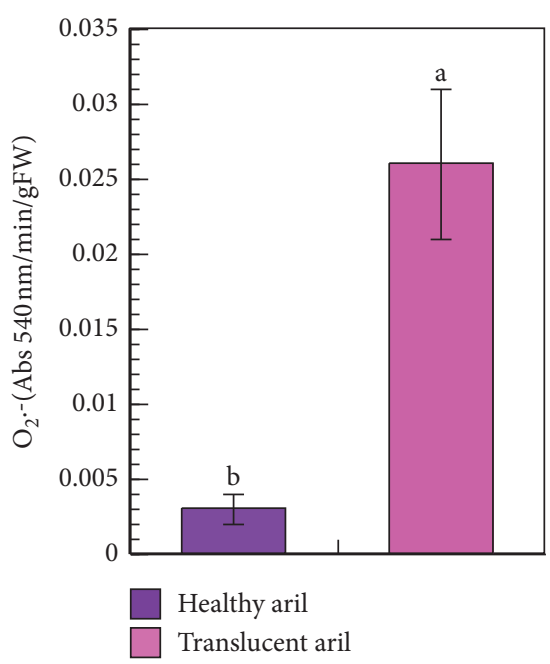

(a)

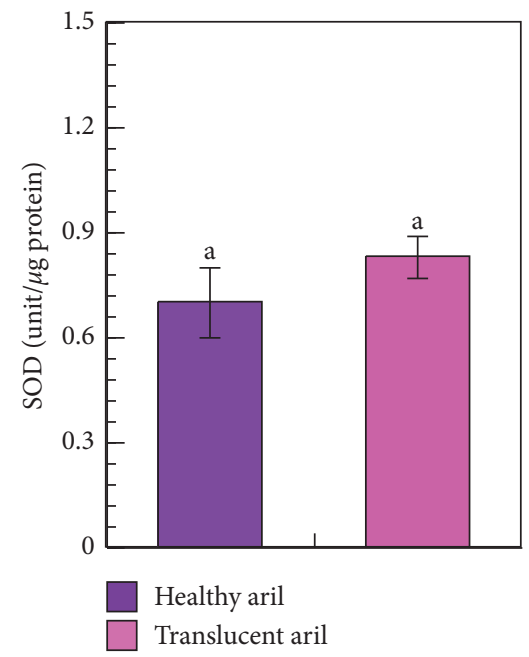

(c)

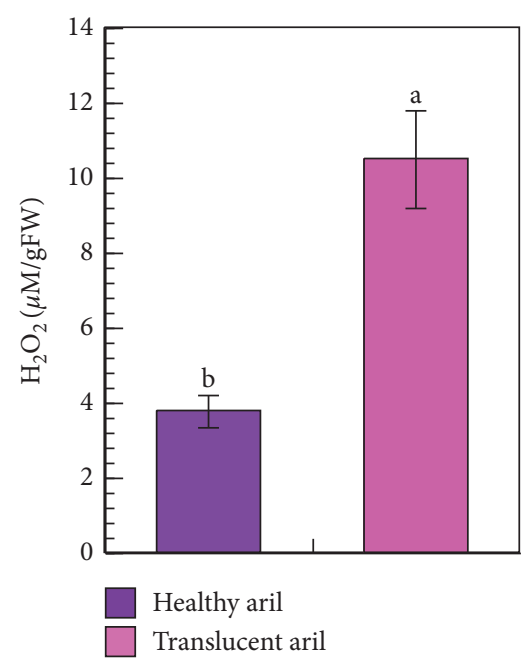

(b)

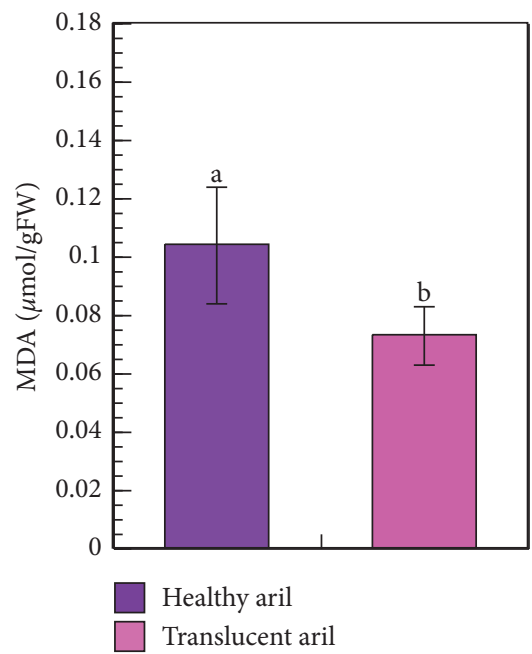

(d)

Figure 2: $\mathrm{O}_{2}^{-}$(a), $\mathrm{H}_{2} \mathrm{O}_{2}$ content (b), superoxide dismutase activity (c), and malonaldehyde content (d) in healthy and translucent arils. Means $(n=4)$ with different lower-case letters on the bars are significantly different.

3.3. The Differential ROS Defensive Mechanisms. The phenolics content was $54 \mathrm{mg} \mathrm{GAE} / \mathrm{g}$ FW in translucent aril and 1.7 times higher than in healthy aril (Figure 3(a)). Since PAL activity was significantly $100 \%$ higher in translucent aril (Figure 3(b)), the phenolics were contributed to form lignin along with the lignified enzyme series. Phenolic biosynthesis could be stimulated by some abiotic stresses such as hypoxia and physical damage to produce phenylpropanoid intermediates as defensive mechanisms of plant cells [32]. Translucent flesh disorder is developed during on-tree fruit ripening in rainy season or when a fruit was covered with water for several hours, which could induce hypoxic conditions in the fruit [5]. Furthermore, the level of transformed $\mathrm{H}_{2} \mathrm{O}_{2}$ can alternatively be reduced by other plant defensive reactions. Although CAT activity, catalyzing $\mathrm{H}_{2} \mathrm{O}_{2}$ into water in peroxisome, was almost equal in both healthy and translucent arils (Figure 3(c)), APX activity in healthy aril was significantly higher than that in translucent aril (Figure $3(\mathrm{~d})$ ). Thus, APX could play a key role in ROS defense in the healthy mangosteen aril by utilizing ascorbic acid and $\mathrm{H}_{2} \mathrm{O}_{2}$ into water via the ascorbate-glutathione cycle [33]. When the lower content of ascorbate by $24 \%$ was detected in translucent aril (Figure 4(a)), the higher range of flavonoids by $35 \%$ was measured in healthy aril (Figure 4(b)). Flavonoids could be an effective antioxidant supplement to reduce the activity of ROS. The supportive evidence was shown by approximately 100\% higher of the high reducing power ability (Figure $4(\mathrm{c})$ ) and potent inhibition of DPPH scavenging in healthy aril (Figure 4(d)). Abiotic stresses inducing antioxidant systems' defensive mechanisms through redox-reaction via ROS metabolism were reported in some field crops $[14,15]$ and horticultural crops [12, 34].

We propose the comparative routes of ROS generation and the defensive mechanism, taking place in the healthy and translucent disorder of ripe mangosteen arils in Figure 5. Translucent aril is an abnormal symptom occurring during fruit ripening on the tree. The initial 


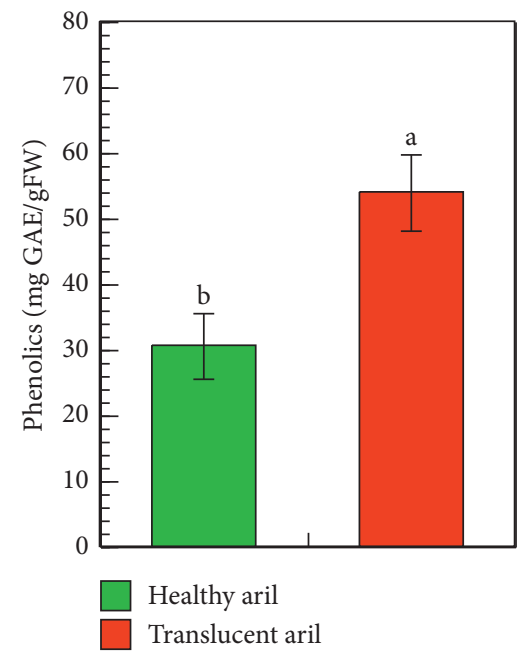

(a)

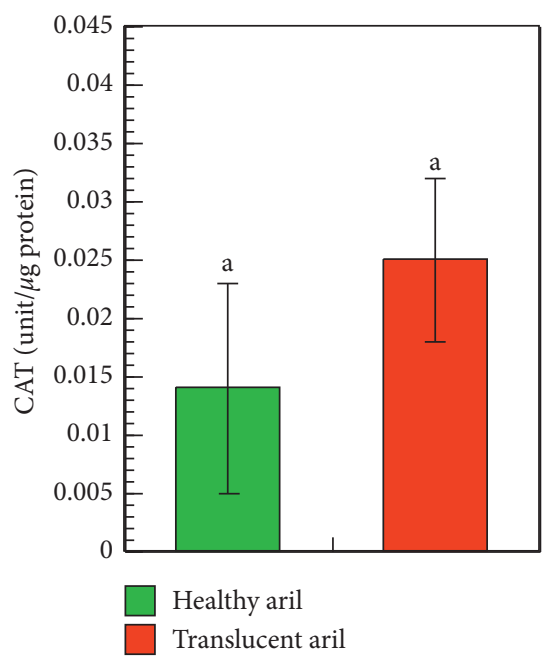

(c)

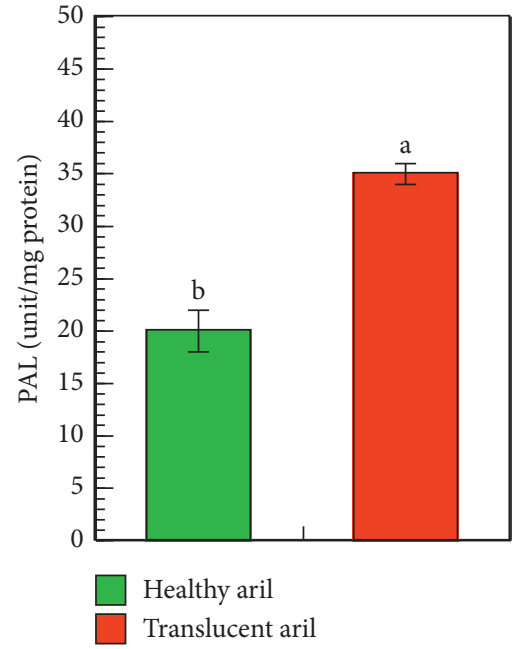

(b)

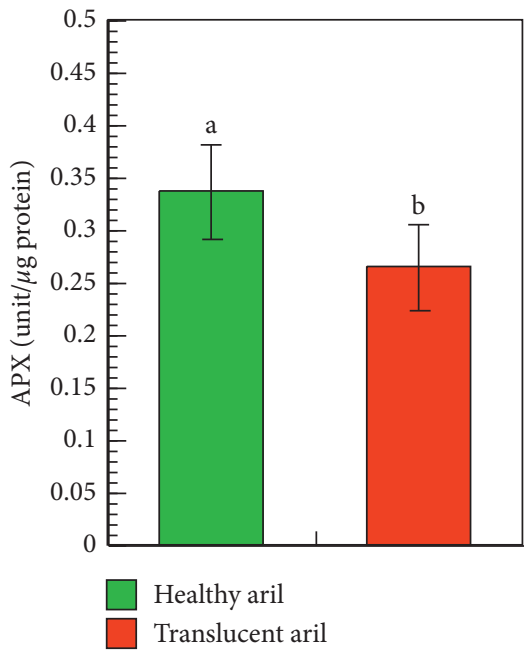

(d)

Figure 3: Phenolic content (a), phenylalanine ammonia lyase activity (b), catalase (c), and ascorbate peroxidase (d) in healthy and translucent arils. Means $(n=4)$ with different lower-case letters on the bars are significantly different.

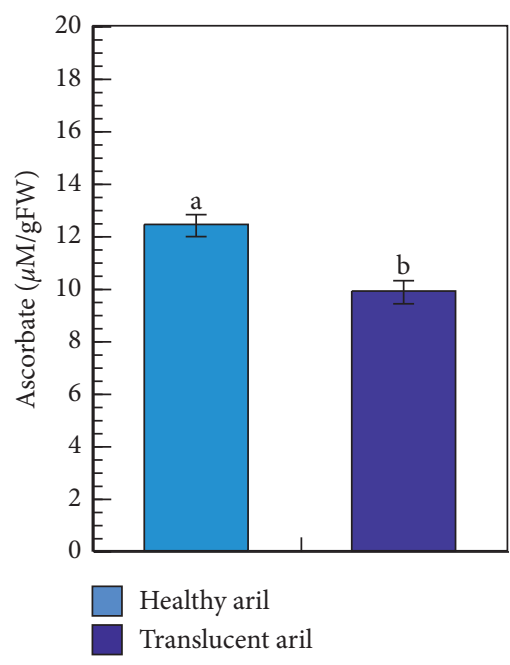

(a)

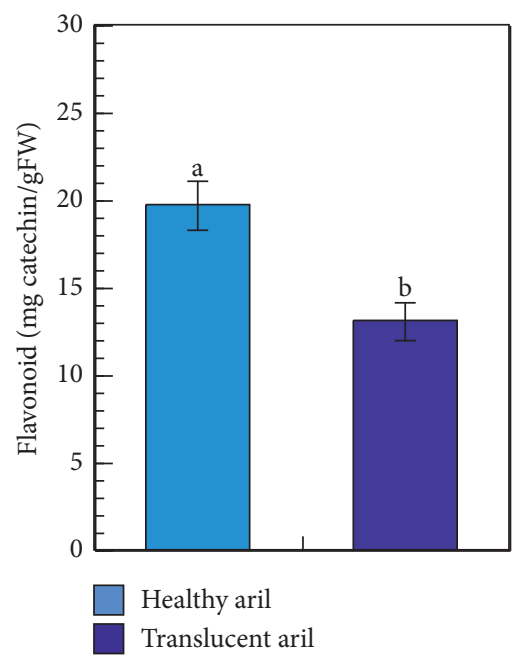

(b)

Figure 4: Continued. 


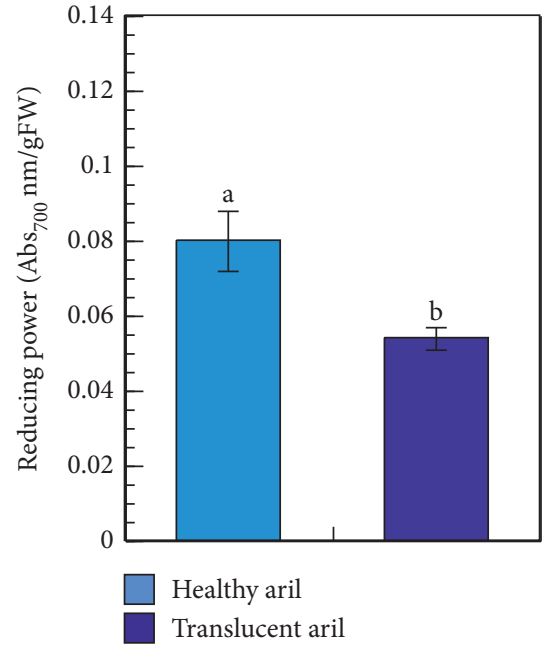

(c)

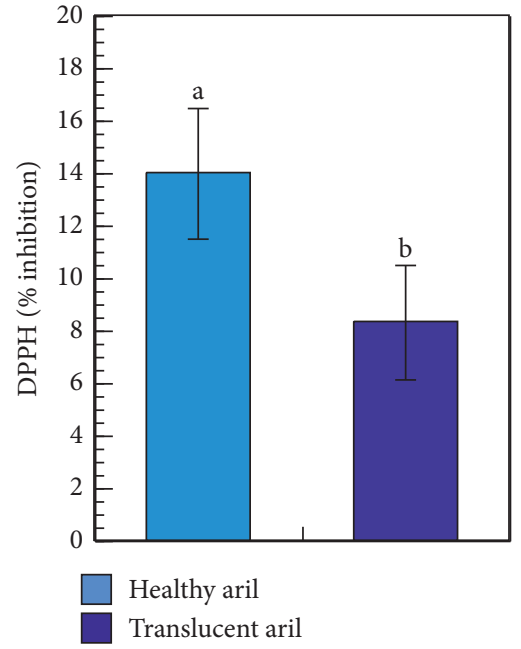

(d)

Figure 4: Ascorbic acid (a), flavonoid content (b), reducing power activity (c), and DPPH inhibition (d) in healthy and translucent arils. Means $(n=4)$ with different lower-case letters on the bars are significantly different.

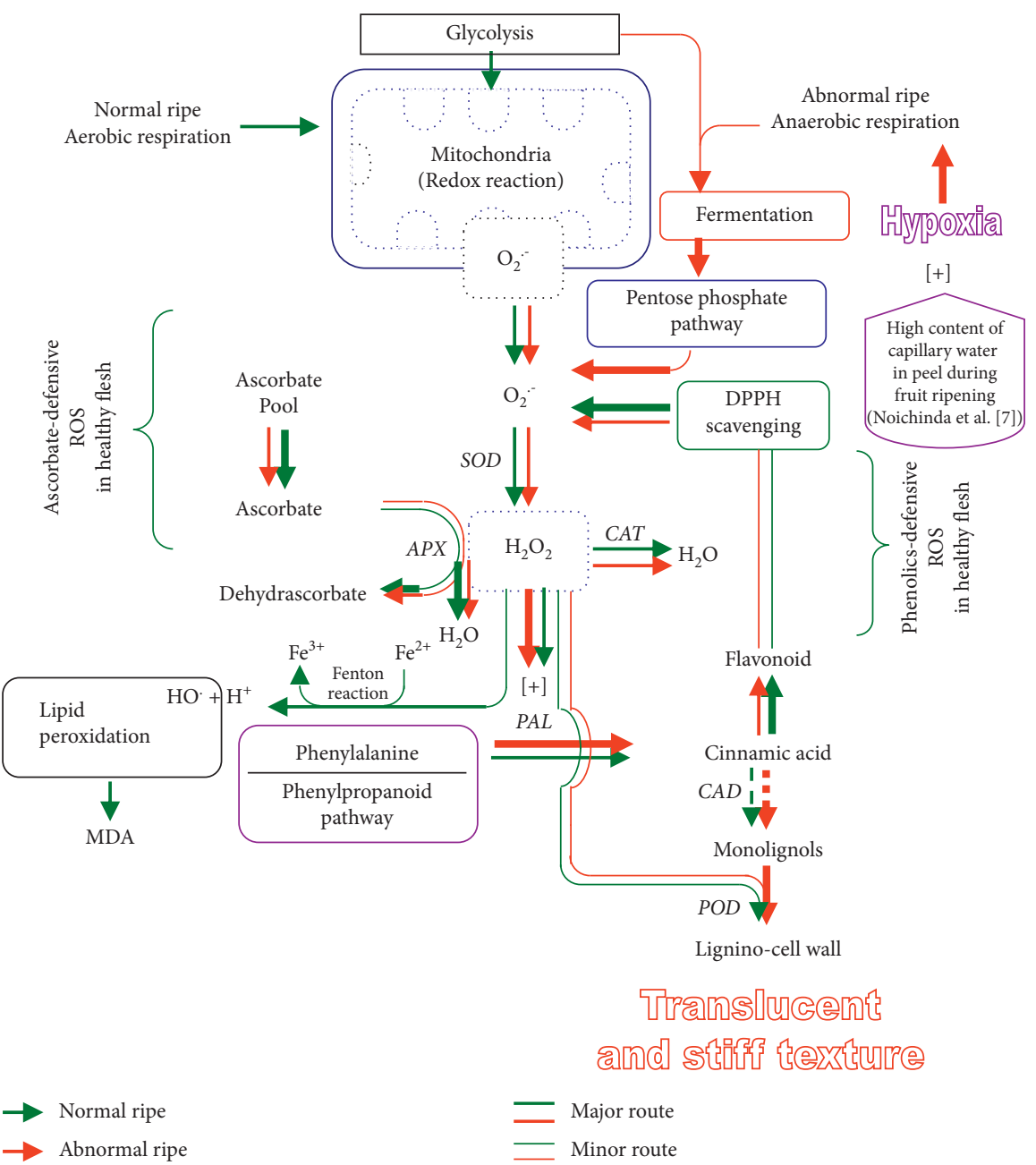

Figure 5: Putative pathways of lignin formation in translucent mangosteen aril related to an increase in phenolics accumulation and the failure of ROS defensive mechanism. 
mechanism is induced under hypoxia by water by applying either rainfalls or artificial water supply over the fruits [7]. Under a hypoxic condition in fruit by full capillary water in the mangosteen pericarp, the living cells of aril lack metabolite-driving energy and so called 'an energy crisis' stress [35]. As a result of survival, cells must produce alternative energy via the fermentation route instead of the typical oxidative phosphorylation. Alternatively, glucose could be dehydrogenated to form ribose via the pentose phosphate pathway. This phenomenal stress is dramatically released of ROS content through the redox-reaction process. Since ROS could further react to lipid peroxidation in the cell membrane, plant cells comprise their defensive mechanism to defend the ROS. SOD can catalyze $\mathrm{O}_{2}^{-}$into $\mathrm{H}_{2} \mathrm{O}_{2}$ (a nonactive ROS form), and $\mathrm{H}_{2} \mathrm{O}_{2}$ is then detoxified into water by CAT. However, due to the low activity of CAT in both healthy and translucent arils instead, APX was important to oxidize $\mathrm{H}_{2} \mathrm{O}_{2}$ and ascorbate into the water in healthy aril, but not in translucent aril. Consequently, a high concentration of remaining $\mathrm{H}_{2} \mathrm{O}_{2}$ could induce the PAL activity to produce cinnamic acid via a translucent aril's phenylpropanoid pathway. This phenolic (cinnamic acid) was derived into two substances. The first was to produce flavonoids, which were potent inhibitors of DPPH in healthy aril. Secondly, cinnamate is dehydrogenated into monolignol by CAD, and the phenolic is then bound to the cell wall by POD. This evidence plays an outstanding role in defense ROS in translucent aril by increasing the cell wall's lignin. In normal aril, high activities of CAT and APX and high content of flavonoids and ascorbate could effectively reduce $\mathrm{H}_{2} \mathrm{O}_{2}$ in the cells. However, the remaining $\mathrm{H}_{2} \mathrm{O}_{2}$ in healthy aril could be further reacted to a vigorous lipid peroxidation form such as $\mathrm{OH}^{-}$when presenting of $\mathrm{Fe}^{2+}$ via Fenton reaction that damaged membrane lipid as indicated by MDA concentration.

\section{Conclusions}

Translucent aril of mangosteen contained high oxidative supplements, whereas normal tissues comprised the better defensive mechanism. Normal aril conducted not only high activities of antioxidant enzymes of superoxide dismutase and ascorbate peroxidase but also high contents of antioxidants of flavonoids and ascorbic acid. Translucent aril reduced a high amount of $\mathrm{H}_{2} \mathrm{O}_{2}$ by inducing lignification of the cell wall through cinnamyl alcohol dehydrogenase and peroxidase, resulting in higher firmness with stiffening structure and crispy texture.

\section{Data Availability}

The supplementary figure data used to support the findings of this study are included within the supplementary information file.

\section{Conflicts of Interest}

The authors declare that they have no conflicts of interest.

\section{Supplementary Materials}

Supplementary Figure 1. Mangosteen fruit with healthy aril (a) and translucent aril (arrow point) (b). (Supplementary Materials)

\section{References}

[1] K. Wanichkul and S. Kosiyachinda, "Fruit development of mangosteen (Garcinia mangostana Linn.)," Agricultural Science Journal, vol. 13, pp. 63-72, 1979.

[2] S. Noichinda, K. Bodhipadma, S. Singkhornart, and S. Ketsa, "Changes in pectic substances and cell wall hydrolase enzymes of mangosteen (Garcinia mangostana) fruit during storage," New Zealand Journal of Crop and Horticultural Science, vol. 35, no. 2, pp. 229-233, 2007.

[3] S. Noichinda, Effect of Modified Atmosphere Condition on Quality and Storage Life Mangosteen (Garcinia mangostana L.) Fruit, MS Thesis, Department of Horticulture, Kasetsart University, Bangkok, Thailand, 1992, in Thai.

[4] C. Wongs-Aree and S. Noichinda, "Postharvest physiology and quality maintenance of tropical fruits," in Postharvest Handling A Systems Approach, W. J. Florkowski, R. L. Shewfelt, B. Brueckner, and S. E. Prussia, Eds., Academic Press is an imprint of Elsevier, Cambridge, MA, USA, 3rd edition, 2014.

[5] S. Noichinda, K. Bodhipadma, and C. Wongs-Aree, "Mangosteen," in Postharvest Physiological Disorders in Fruits and Vegetables, S. Tonetto de Freitas and S. Pareek, Eds., CRC Press, Boca Raton, FL, USA, 2019.

[6] P. Chuennakorn, P. Paiboon, and S. Yingjajaval, Rate of Water Flow and the Occurrence of Gamboges and Translucent Flesh Disorders in Mangosteen Fruit, Center for Agricultural Biotechnology, Kasetsart University, Kamphaeng Saen Campus, Nakhon Pathom, Nakhon, Thailand, in Thai, 2011.

[7] S. Noichinda, K. Bodhipadma, and S. Kong, "Capillary water in pericarp enhances hypoxic condition during on-tree fruit maturation that induces lignification and triggers translucent flesh disorder in Mangosteen (Garcinia mangostana L.)," Journal of Food Quality, vol. 2017, Article ID 7428959, 7 pages, 2017.

[8] V. Luckanatinvong, The study on chemical composition, cell viability and influence of water on flesh translucent disorder in mangosteen (Garcinia mangostana L.), MS Thesis, Department of Horticulture, Kasetsart University, Bangkok, Thailand, 1996, in Thai.

[9] J. Siritikul, S. Noichinda, K. Bodhippadma, and C. WongsAree, "Aril and seed viabilities related to the developmental stage of translucent pulp in mangosteen," Agricultural Science Journal, vol. 45, no. 2, pp. 561-564, 2014.

[10] T. Nguyen, S. Son, M. C. Jordan, D. B. Levin, and B. T. Ayele, "Lignin biosynthesis in wheat (Triticum aestivum L.): its response to waterlogging and association with hormonal levels," MBC Plant Biology, vol. 16, no. 28, 2016.

[11] L. Jia, X. Qin, D. Lyu, S. Qin, and P. Zhang, "ROS production and scavenging in three cherry rootstocks under short-term waterlogging conditions," Scientia Horticulturae, vol. 257, Article ID 108647, 2019.

[12] S. Phornvillay, N. Prongprasert, C. Wongs-Aree, A. Uthairatanakij, and V. Srilaong, "Physio-biochemical responses of okra (Abelmoschus esculentus) to oxidative stress under low temperature storage," The Horticulture Journal, vol. 89, no. 1, pp. 69-77, 2020. 
[13] M. H. Siddiqui, S. Alamri, M. Nasir Khan et al., "Melatonin and calcium function synergistically to promote the resilience through ROS metabolism under arsenic-induced stress," Journal of Hazardous Materials, vol. 398, Article ID 122882, 2020.

[14] A. A. Alsahli, J. A. Bhat, M. N. Alyemeni, M. Ashraf, and P. Ahmad, "Hydrogen sulfide (H2S) mitigates arsenic (As)Induced toxicity in pea (Pisum sativum L.) plants by regulating osmoregulation, antioxidant defense system, ascorbate glutathione cycle and glyoxalase system," Journal of Plant Growth Regulation, vol. 166, 2020.

[15] C. Kaya, M. Ashraf, M. N. Alyemeni, F. J. Corpas, and P. Ahmad, "Salicylic acid-induced nitric oxide enhances arsenic toxicity tolerance in maize plants by upregulating the ascorbate-glutathione cycle and glyoxalase system," Journal of Hazardous Materials, vol. 399, Article ID 123020, 2020.

[16] T. P. O’Brien, N. Feder, and M. E. McCully, "Polychromatic staining of plant cell walls by Toluidine-blue O," Phytoplasma, vol. 59, pp. 367-373, 1964.

[17] R. J. Bruce and C. A. West, "Elicitation of lignin biosynthesis and isoperoxidase activity by pectic fragments in suspension cultures of Castor bean," Plant Physiology, vol. 91, no. 3, pp. 889-897, 1989.

[18] K. S. K. Chaitanya and S. C. Naithani, "Role of superoxide, lipid peroxidation and superoxide dismutase in membrane perturbation during loss of viability in seeds of Shorea robusta Gaertn.f." New Phytologist, vol. 126, no. 4, pp. 623-627, 1994.

[19] M. Zouari, C. Ben Ahmed, W. Zorrig et al., "Exogenous proline mediates alleviation of cadmium stress by promoting photosynthetic activity, water status and antioxidative enzymes activities of young date palm (Phoenix dactylifera L.)," Ecotoxicology and Environmental Safety, vol. 128, pp. 100-108, 2016.

[20] R. S. Dhindsa, P. Plumb-Dhindsa, and T. A. Thorpe, "Leaf senescence: correlated with increased levels of membrane permeability and lipid peroxidation, and decreased levels of superoxide dismutase and catalase," Journal of Experimental Botany, vol. 32, no. 1, pp. 93-101, 1981.

[21] A. Jiménez, J. A. Hernández, L. A. del Rio, and F. Sevilla, "Evidence for the presence of the ascorbate-glutathione cycle in mitochondria and peroxisomes of Pea leaves," Plant Physiology, vol. 114, no. 1, pp. 275-284, 1997.

[22] D. Goffner, I. Joffroy, J. Grima-Pettenati et al., "Purification and characterization of isoforms of cinnamyl alcohol dehydrogenase fromEucalyptus xylem," Planta, vol. 188, no. 1, pp. 48-53, 1992.

[23] H. Song, X. Gao, B. Feng et al., "Leaf senescence and physiological characters in different Adzuki bean (Vigna angularis) cultivars (lines)," African Journal of Agricultural Research, vol. 8, pp. 4025-4032, 2013.

[24] S. Dipierro and S. De Leonardis, "The ascorbate system and lipid peroxidation in stored potato (Solanum tuberosum L.) tubers," Journal of Experimental Botany, vol. 48, no. 3, pp. 779-783, 1997.

[25] M. C. Recuenco, M. S. Lacsamana, W. A. Hurtada, and V. C. Sabularse, "Total phenolic and total flavonoid contents of selected fruits in the Philippines," Philippine Journal of Science, vol. 145, pp. 275-281, 2016.

[26] E. L. Camm and G. H. N. Towers, "Phenylalanine ammonia lyase," Phytochemistry, vol. 12, no. 5, pp. 961-973, 1973.

[27] B. P. Klein and A. K. Perry, "Ascorbic acid and vitamin A activity in selected vegetables from different geographical areas of the United States," Journal of Food Science, vol. 47, no. 3, pp. 941-945, 1982.
[28] C.-H. Chang, H.-Y. Lin, C.-Y. Chang, and Y.-C. Liu, "Comparisons on the antioxidant properties of fresh, freezedried and hot-air-dried tomatoes," Journal of Food Engineering, vol. 77, no. 3, pp. 478-485, 2006.

[29] M. M. Bradford, "A rapid and sensitive method for the quantitation of microgram quantities of protein utilizing the principle of protein-dye binding," Analytical Biochemistry, vol. 72, no. 1-2, pp. 248-254, 1976.

[30] P. Schopfer, "Hydrogen peroxide-mediated cell-wall stiffening in vitro in maize coleoptiles," Planta, vol. 199, pp. 43-49, 1996.

[31] M. W. Davey, E. Stals, B. Panis, J. Keulemans, and R. L. Swennen, "High-throughput determination of malondialdehyde in plant tissues," Analytical Biochemistry, vol. 347, no. 2, pp. 201-207, 2005.

[32] C. Wongs-Aree and S. Noichinda, "Glycolysis fermentative by-products and secondary metabolites involved in plant adaptation under hypoxia during pre- and postharvest," in Hypoxia and Anoxia, K. Das and M. S. Biradar, Eds., IntechOpen, London, UK, 2018.

[33] T. Ushimaru, Y. Maki, S. Sano, K. Koshiba, K. Asada, and $\mathrm{H}$. Tsuji, "Induction of enzymes involved in the ascorbatedependent antioxidative system, namely, ascorbate peroxidase, monodehydroascorbate reductase and dehydroascorbate reductase, after exposure to air of rice (Oryza sativa) seedlings germinated under water," Plant and Cell Physiology, vol. 38, no. 5, pp. 541-549, 1997.

[34] W. W. Lwin, V. Srilaong, P. Boonyaritthongchai, C. WongsAree, and N. Pongprasert, "Electrostatic atomized water particles reduces postharvest lignification and maintain asparagus quality," Scientia Horticulturae, vol. 271, Article ID 10948, 2020.

[35] T. Fukao and J. Bailey-Serres, "Plant responses to hypoxia - is survival a balancing act?" Trends in Plant Science, vol. 9, no. 9, pp. 449-456, 2004. 